\title{
Understanding the present, re-visioning the future: An initial mapping of music therapists in the United Kingdom
}

\begin{abstract}
Background: Music therapy is a small, but evolving profession. Numbers of music therapists are increasing, yet little is known regarding the workforce and its employment characteristics. To understand the current profile of the music therapy workforce in the United Kingdom (UK), the British Association for Music Therapy (BAMT) commissioned a national survey of its membership.
\end{abstract}

Aim: This survey explores the profile of the UK music therapy workforce in terms of demographics, training and employment characteristics.

Method: An online survey was circulated to all BAMT members. Data were analysed using descriptive statistics and thematic analysis of open ended responses.

Results: A total of 374 therapists responded (44\% response rate). Following demographic information (including age, nationality and training background), we 
focus on employment characteristics such as income, types of work, settings, clients and age groups. Supervision and clinical fees are considered as well as commissioning and funding of self-employed and employed music therapy work.

Discussion: As an initial mapping of the current UK workforce, this study offers a pragmatic platform to consider development and strategic priorities and thus to re-vision the future of music therapy in the country. Potential implications for the international music therapy community are also discussed.

\section{Keywords}

Music therapists, employment, survey, United Kingdom, British Association for Music Therapy 


\section{Introduction}

Music therapy is a relatively small, evolving profession and discipline with advances in practice, training and research. In the last few years, Bunt and Stige (2014) have described paths of development in music therapy (see also Ridder \& Tsiris, 2015a), while Aigen (2014) has referred to different stages of development in models of music therapy and associated theory. More specific to the United Kingdom (UK), Barrington's 2005 study examined the process of professionalisation of music therapy within the UK up to that point in time. Such developments are influenced not only by the immediate contexts of work, but wider societal, economic and political factors (Ansdell \& Pavlicevic, 2008).

As the profession and discipline of music therapy grows, overview studies help us to develop an understanding of how historic developments and the present situation can inform future initiatives. Examples include: emerging conceptual frameworks (e.g. Bonde, 2011), mappings of practices in music therapy and related music and health fields (e.g. MacDonald, Kreutz \& Mitchell, 2012), summaries of different music therapy models (e.g. Bruscia, 1987; Spiro, Tsiris \& Pavlicevic, 2014; Trondalen \& Bonde, 2012) and development of the music therapy profession 
across different countries (e.g. Dileo-Maranto, 1993; Ridder \& Tsiris, 2015b; Stegemann, Schmidt, Fitzthum \& Timmermann, 2016).

A further area, which is also the focus of this paper, regards overviews of salary or employment trends within countries or professional bodies. This has been most prominent in the United States of America (USA) with surveys from both within and outside the American Music Therapy Association (AMTA, 2014). Such surveys have explored music therapist demand (Groene, 2003), employment and membership trends (Silverman \& Furman, 2014), community music therapy (Curtis, 2015) and gatekeeping practices (Hsiao, 2014). Continued international interest in music therapist employment is evidenced by a more recent survey by the World Federation of Music Therapy (WFMT, 2016).

Although generally retrospective, such studies provide frameworks which inform future research and disciplinary initiatives. These in turn underpin policy and strategic professional decision-making. Overviews of salary and employment trends can serve a multitude of functions to stakeholders. Music therapists, for example, need to know how much to charge for sessions and where areas of growth for work are. Potential trainees often wish to know what working practice 
and salaries are like before committing valuable resources to training. For professional bodies, employment information provides the necessary evidence to support lobbying initiatives which underpin new areas of work and identify areas of need. In addition, government, charities and commissioners of services need to know the potential for and scope of music therapy work. An understanding of the current profile of music therapists and their employment characteristics is therefore of relevance in answering such questions.

Given the importance of such questions, this study provides an initial mapping of the UK music therapy workforce. It aligns itself with recent debates in the field: drawing from the past and reflecting on the future of music therapy in the UK, Maratos (2014) calls for a collaborative approach working towards a more shared identity and vision within the profession. The need to consider "leadership, funding and workforce" in relation to professional and workforce development was also stressed recently at the Scottish Allied Health Professions (AHP) Parliamentary debate (Scottish Parliament, 2015; see also Maclean \& Pestell, 2016), whilst the Centre for Workforce Intelligence (CfWI, 2013) identified a need for workforce capacity assessments of psychological therapists. An overview from within the music therapy profession, therefore, provides a critical contribution to 
these debates, particularly considering the diversity of client groups, settings and funders engaging with music therapists.

\section{A note on music therapy in the UK}

Some have argued that UK music therapists "have never had it so good" (BAMT, 2015a). Indeed, when considering the wider European context (Ridder \& Tsiris, 2015b), the UK appears to be in a strong position: it is one of the three European countries where the music therapy profession is recognised by the State, one of the largest employers is the country's National Health Service (NHS) and music therapy is included in the National Institute for Health and Care Excellence (NICE) guidelines for certain diagnostic groups (Barrington, 2015; Odell-Miller, 2016). This picture is strongly linked to the growing research activity within the country where an increasing number of doctoral research projects, research initiatives funded by the National Institute for Health Research (e.g. Carr, Odell-Miller \& Priebe, 2013; Carr, O’Kelly, Sandford \& Priebe, 2017; Geretsegger, Holck \& Gold, 2012), international collaborations (e.g. Stige, Ansdell, Elefant \& Pavlicevic, 2010) and consortiums (e.g. The International Consortium of Music Therapy Research Universities) are observed. 
As a regulated profession by the Health and Care Professions Council (HCPC), there are commonly agreed standards regarding training, supervision and professional development and seven masters training programmes in the UK (Barrington, 2015; Watson, 2015). ${ }^{1}$ Despite their shared focus on improvisational music therapy, these training programmes differ in terms of the theories and approaches underpinning their orientations. This plurality, which is equally reflected in practitioners' diverse identities and ways of practising, is further enhanced by other emerging trainings. The latter include training opportunities in Guided Imagery and Music (GIM) and specialisations, such as Neurologic Music Therapy, some of which are linked to particular research and assessment approaches (e.g. the Music Therapy Assessment Tool for Awareness in Disorders of Consciousness (MATADOC), see Magee et al., 2014).

The financial climate within the UK, however, is placing enormous pressures upon health, social care and education. In 2016, a funding gap of $£ 1.9$ billion was estimated in social care despite 6 successive years of budget reductions (Nuffield Trust, The Health Foundation \& The King's Fund, 2016). Within the NHS, funding

\footnotetext{
${ }^{1}$ For additional information and historic accounts regarding music therapy in the UK, see Tyler (2000), Ansdell, Bunt and Hartley (2002), Barrington (2005), and Odell-Miller and Sandford (2009).
} 
has been limited, leading to service cuts, despite increasing demand for services. Such pressures have impacted upon access to care, leading to delayed discharges from hospital and increased burden upon family and carers in the community. A similar picture is seen in education, where authorities are challenged to make efficiency savings of around $£ 3$ billion within the next 3 years alongside rising numbers of pupils (National Audit Office, 2016). The recent vote for the UK to leave the European Union (EU) may also have an impact including staffing of services and uncertainty regarding further changes to the wider economy (McKenna, 2016).

The British Association for Music Therapy (BAMT)2 counted a total of 1006 members in August 2015. The breakdown of members per membership type at this point in time (BAMT, 2015b) was as follows:

- Practitioner members ( $N=669$ ): Practising, qualified HCPC registered music therapists, of which 61 were newly qualified practitioners (in their first year of registration with BAMT);

- Non-practising or overseas members ( $N=109)$ :

${ }^{2}$ BAMT replaced the Association of Professional Music Therapists (APMT) and British Society for Music Therapy (BSMT) in April 2011. 
- Trainee members ( $N=64)$ : Enrolled on an HCPC approved music therapy training;

- Individual and corporate associate members ( $N=164)$ : Individuals and organisations interested in music therapy and promoting the objects of BAMT.

To date, few surveys have been conducted of UK music therapy employment. Stewart (2000) surveyed employment, support networks and job satisfaction of music therapists in 1997 following observations of geographical isolation and reduced membership renewals. Fifty percent of the 250 registered practitioners responded. At that time, 88\% reported they had secured "enough work" since training. On average, respondents worked 3.4 days per week, whilst $52 \%$ had 4 or more days' work per week. Part-time posts were held by $42 \%$ of respondents, with $24 \%$ holding self-employed work and $16 \%$ holding full-time posts. In terms of client groups, $43 \%$ of work was within learning disabilities and $11 \%$ in mental health.

The most recent membership survey of the association (APMT, 2010) was based on membership renewal returns of 475 practitioner members and provided data on geographical location, nature of employment, and client groups. Most members were based in London (27\%) and the south of England (32\%) with only 11\% in 
Scotland, Wales and Northern Ireland. The most common client group was children, learning disabilities (73\%) and mental health (44\%), with only 5\% working with adolescents and 6\% with elderly populations. Half of members were employed by an organisation, whilst 35\% held self-employed work only and 15\% a combination of both.

Today, and despite the financial pressures, the number of HCPC registered music therapists is still growing, (having almost doubled within the last ten years) and this rate of growth is greater than the other Allied Health Professions (Sandford, 2016). ${ }^{3}$ At the same time, Maratos (2014) observed that following the qualification of 204 music therapy students from UK trainings between 2010 and 2013, only 75 new therapists appeared on the HCPC register, and she questioned to what extent this observation relates to the current job market.

Given the growth since the 2009 survey of the APMT (now BAMT) (APMT, 2010), the need to understand the current state of music therapy employment is particularly apparent. An understanding of the current profile of the UK music therapy workforce can provide a platform to inform music therapists, professional

\footnotetext{
${ }^{3}$ Between 2006 and 2016, the number of HCPC registered music therapists has grown from 528 to 951 (Sandford, 2016).
} 
bodies and service providers regarding the context of music therapy work in the

UK.

\section{The study}

In 2015, BAMT commissioned a national survey of its membership which was conducted in collaboration with Goldsmiths, University of London. The study aimed to provide an initial mapping of music therapists working in the UK in terms of demographics, training and employment characteristics. The study also included the first stage of an ongoing broader research project which seeks to explore cultural issues in the music therapy profession. ${ }^{4}$ The study was approved by the Goldsmiths Research Ethics and integrity Committee (Reference Number: EA 1239).

\footnotetext{
${ }^{4}$ Survey respondents were asked for their views on priorities for research into culture and cultural issues in music therapy as well as their willingness to be contacted regarding future research. Their responses are not included in the reporting of the results as they are beyond this survey's scope. It is worth mentioning, however, that 189 respondents offered ideas on how culture intersects with music therapy and 161 wished to be contacted for a follow-up study. Suggestions for future research inquiry included themes around specific musical genres, materials, instruments and languages, institutional and funding cultures, spirituality and religion, music therapists' professional and cultural identities, meeting the needs of diverse populations, employment and training, diversity and engagement of communities with music therapy and modern technologies and their use in music therapy practice. For further information, please contact the third author who is the principal researcher of the ongoing research project.
} 


\section{Data collection and sample}

Data were collected through an online survey questionnaire. ${ }^{5}$ The survey was open for five months (from 1 April to 31 August 2015) and all BAMT members who were qualified or trainee music therapists were invited to participate. This included all individuals $(\mathrm{N}=842)$ with practitioner, non-practising (career break, transitional and retired), overseas or trainee membership type.

The survey link, as well as any follow-up emails, were circulated by the BAMT Office. Information was also made available through the BAMT website and ebulletins.

\section{Survey design}

The survey was developed using the Bristol Online Surveys tool (Bristol Online Surveys, 2015). To ensure that the survey covered areas of strategic importance, the questions were formulated in consultation with Grace Watts (PR Officer of BAMT) and Donald Wetherick (Chair of BAMT Trustees, November 2012- October 2015) and other BAMT Trustees. At the same time, the survey structure and content were informed - where relevant and appropriate - by other similar

\footnotetext{
5 The questionnaire is freely available on the BAMT website (Carr, Tsiris \& Swijghuisen Reigersberg, 2017).
} 
surveys (e.g. APMT, 2010; Silverman \& Furman, 2014) and wider music therapy literature. For instance, the increased emphasis on community music therapy in the UK and beyond (Stige \& Aarø, 2011; Tsiris, 2014), as well as recent research initiatives that explored the profile of practitioners who identify themselves as 'community music therapists' (Curtis, 2015), led to questions regarding three formats of music therapy work: individual, group and 'community music therapy' work.

Such literature as well as the existing BAMT membership renewal form influenced the way that client groups, salary bandings and certain demographic information were categorised. Skip logic (Bristol Online Surveys, 2017) was used to help route respondents through the questions since different sections and combinations of survey questions were relevant to different sub-groups of respondents depending on their membership and employment status. For example, if respondents answered "no" to self-employment, they were automatically routed to the next set of questions, skipping all questions relating to self-employment. 
Data analysis

Responses were screened for duplicates and eligibility criteria. In some cases respondents reported difficulties in providing accurate or full information in certain sections of the survey. These cases were checked jointly by the first and second author. Where issues were clearly indicated, retrospective refinements of the provided responses were made.

As the aim of the study was to describe characteristics, we used descriptive statistics to provide an overview of the frequencies and spread of the data (Field, 2009). For categorical data, we provide the frequencies and percentages for each category. For continuous data (such as age) we have provided the average, the range (maximum and minimum), mode and standard deviation (s.d.). The standard deviation is a measure of how much individual responses differ from the group average. Higher values indicate a greater variation, whist lower values indicate less variation. The data was analysed using statistical software (Stata, version 14; Statacorp, 2015).

We provided opportunities for open ended responses throughout the survey to help respondents describe their work if this did not fit with response options 
provided ('other' responses). These were coded by content, grouped into similar themes (Teddlie \& Tashakkori, 2009) and are reported in the corresponding sections.

\section{Results}

After screening of the initial dataset for duplicates and eligibility criteria, a total of 374 valid survey respondents ( $44 \%$ response rate) were analysed (Figure 1). 


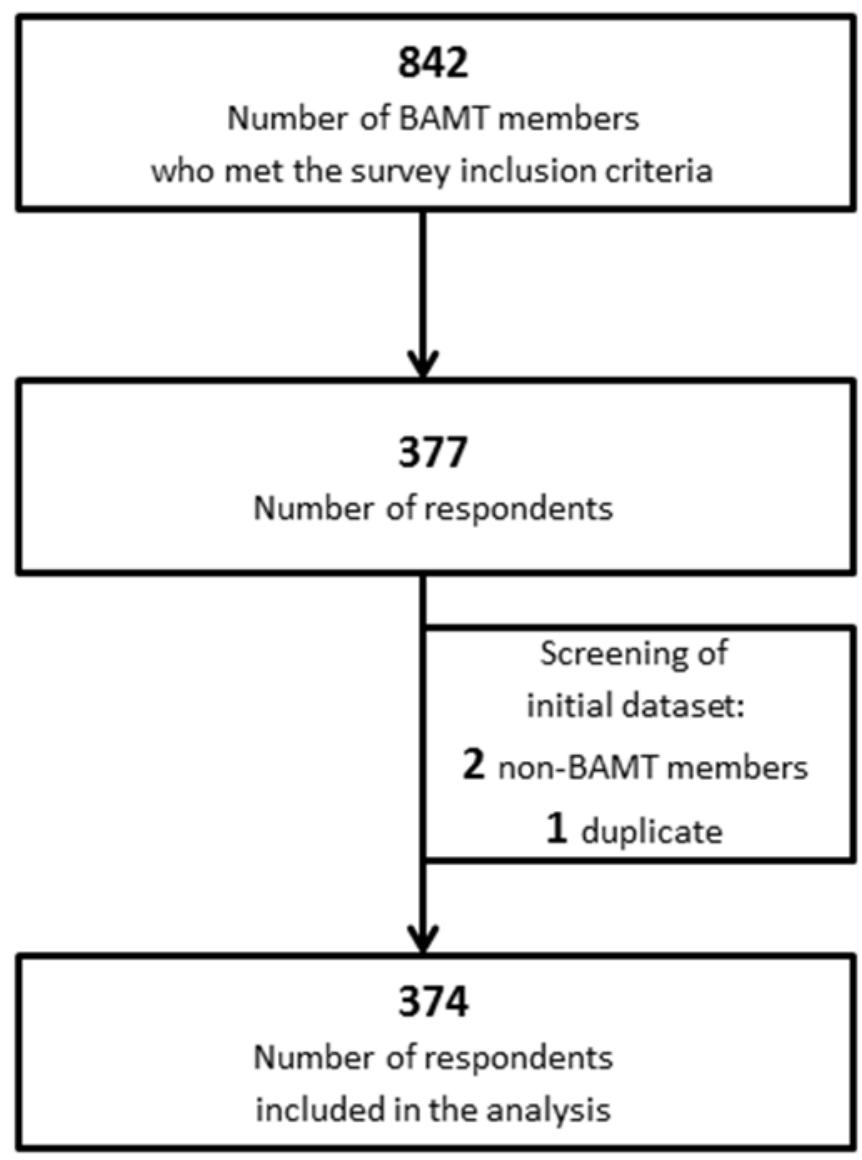

Figure 1: Respondents and data screening

Following demographic characteristics, the findings focus on employment characteristics including work settings, client and age groups, as well as fees, commissioning and funding. Unless otherwise reported, the responses of trainee, retired and overseas members are excluded as most questions were specific to 
current employment within the UK. The findings are reported here as accurate at the time of the survey conduction. A report including the full set of tables from this analysis is available on request from BAMT.

\section{Demographics}

A total of 374 individuals responded to the survey (44\% response rate) representing all the UK regions. The majority of respondents were female $(\mathrm{N}=284$, 78\%), 41-50 years old $(\mathrm{N}=108,30 \%)$ and practitioner members $(\mathrm{N}=327,87 \%)$ (Figure 2). The majority of non-trainee respondents qualified in 2005 or later $(\mathrm{N}=168,52 \%)$.

\section{$<$ Insert figure 2 here $>$}

Most (excluding the overseas respondents) had British nationality ( $N=316,87 \%) .{ }^{6}$ A small number had nationalities from countries within Europe (8\%), North America (3\%), Asia (2\%) or Africa (>1\%). Likewise, the majority identified their ethnicity as 'white: English/Welsh/Scottish/Northern Irish/British' (81\%) and a smaller number as 'other white' (12\%), 'Asian/Asian British' (3\%), 'mixed/multiple ethic groups' (2\%), 'Black/African/Caribbean/Black British' $(>1 \%)$, and other ethnic groups $(>1 \%)$.

\footnotetext{
6 This includes those who reported 'British', 'joint British and other nationality', 'Scottish', 'English', 'Northern Irish' or 'Welsh'.
} 
The majority of practitioners were between 31-50 years of age whilst trainees were between 20-30 years old (Figure 3).

$<$ Insert figure 3 here $>$

Respondents represented all the UK music therapy training programmes. The majority of those with 'other' training had completed training at the University of Limerick, Ireland or overseas (Figure 4). ${ }^{7}$

$<$ Insert figure 4 here $>$

Just under half of respondents $(\mathrm{N}=170,45 \%)$ reported additional professional qualifications or accreditations relevant to their music therapy work with the most common occurrences being: pychotherapeutic or counselling related qualifications $(\mathrm{N}=40)$, Postgraduate Certificate in Education (PGCE) $(\mathrm{N}=17), \mathrm{PhD} / \mathrm{MPhil}(\mathrm{N}=15)$,

7 Some training programmes changed over time. In Figure 4, "Queen Margaret University, Edinburgh" includes respondents who completed the training at "Nordoff-Robbins, University of Edinburgh". The latter moved to Queen Margaret University and in 2015 ceased to be a NordoffRobbins specific programme. Likewise, "University of the West of England, Bristol" includes those who completed the training at "University of Bristol". The Royal Welsh College of Music and Drama closed in 2008. Finally, the London-based Nordoff Robbins training expanded in 2011 to include another base in Manchester. (Barrington, 2015). 
Neurologic Music Therapy ( $\mathrm{N}=9$ ), and GIM (N=5). In addition, some reported currently undertaking further training with the most common being psychotherapy or counselling related trainings and GIM.

Two thirds $(\mathrm{N}=239 ; 69 \%)$ were not a member of a union. Only $16 \%$ were members of UNITE and UNISON which are suggested as unions by BAMT.

\section{Employment characteristics ${ }^{8}$}

Practitioner employment. The majority of practitioners (N=305, 93\%) were employed and working as a music therapist, while 4\% were not employed as music therapists and were seeking such employment. Three percent held other types of non-music therapy employment. Through the open-ended responses, $4 \%$ noted that they had 'honorary' or zero hours contracts.

The majority $(\mathrm{N}=304,89 \%)$ reported that their first music therapy employment was paid. Most of those whose first employment was unpaid qualified from 2003

\footnotetext{
${ }^{8}$ Employment characteristics refer only to qualified music therapists who are BAMT members and working in the UK $(\mathrm{N}=327)$. Where relevant we make a distinction between employed and selfemployed music therapists, but in many cases respondents were both employed and self-employed.
} 
onwards ( $\mathrm{N}=28,80 \%$ of respondents whose first post was unpaid). In open-ended responses, some indicated their opposition to such posts or contracts and some referred more broadly to the ongoing difficulties in terms of finding music therapy employment.

Music therapists qualifying in the last six years (2009 onwards, $N=114$ ) were asked how long it had taken them to find music therapy work. Most had found work either before qualifying $(\mathrm{N}=26,23 \%)$ or within 6 months $(\mathrm{N}=66,59 \%) ; 12 \%$ $(\mathrm{N}=14)$ of respondents took between $7-12$ months, whilst $3 \%(\mathrm{~N}=3)$ had not yet found music therapy work.

Number of employment roles and proportion of time employed. The majority $(\mathrm{N}=291,89 \%)$ of respondents reported at least one employment role, of which, $186(57 \%)$ undertook some form of self-employed work. Ninety $(28 \%)$ were fully self-employed; 133 (41\%) held only contracted employment and 88 (27\%) had a mixture of both. 
Of those with a contracted employer, 160 (49\%) had one employer only, while $113(34 \%)$ had two or three employers and 12 (4\%) had 4 or more (Figure 5).

$$
<\text { Insert figure } 5 \text { here }>
$$

Respondents reported a range of whole time equivalent (WTE) employments. Average employment was 3 days per week (0.6 WTE, s.d. .296). The largest single WTE category of employment was full time, for just under one fifth of therapists $(\mathrm{N}=54,18 \%)$.

Music therapists who were fully self-employed tended to work up to 3 days per week (85\%). Those with no self-employed work tended to work 3 or more days per week (76\%). Music therapists with a mixture of employed and self-employed work, tended to work with their employer up to 2 days per week (49\%) and supplement this with 1-2 days per week of self-employed work (87\%).

Just over two thirds ( $\mathrm{N}=206,70 \%)$ of employed music therapists had at least one other music therapist in their immediate team and $40 \%(\mathrm{~N}=110)$, another arts 
therapist. Self-employed therapists reported fewer arts therapists in their immediate team. Just under half (48\%) had another music therapist in their team whilst only a quarter (25\%) had another arts therapist (Figure 6).

$<$ Insert figure 6 here>

Annual gross income. Income from music therapy related work (including clinical, research, supervision and management work) ranged from $£ 0$ to $£ 65,000-£ 69,000$. One fifth (20\%) earned less than $£ 10,000$ per year from music therapy work, with $3 \%$ earning no music therapy income. The most common income $(28 \%, N=87)$ was between $£ 20,000-£ 29,999$. Around half of the respondents did not have extra income from non-music therapy work (48\%). Total gross income was spread between $£ 10,000-£ 40,000$, for $78 \%$ of respondents $(N=210)$ (Table 1$)$. 
Table 1. Income from music therapy and other work.

\begin{tabular}{|c|c|c|c|}
\hline $\begin{array}{l}\text { Annual gross } \\
\text { income }\end{array}$ & $\begin{array}{l}\text { music therapy } \\
\text { income } \\
\text { Frequency }(\%) \\
(\mathrm{N}=315)\end{array}$ & $\begin{array}{c}\text { non-music therapy } \\
\text { income } \\
\text { Frequency }(\%) \\
(\mathrm{N}=305)\end{array}$ & $\begin{array}{c}\text { Total } \\
\text { gross } \\
\text { income } \\
\text { Frequency } \\
(\%) \\
(\mathrm{N}=298) \\
\end{array}$ \\
\hline Prefer not to say & $11(3 \%)$ & $15(5 \%)$ & $0(0 \%)$ \\
\hline $\begin{array}{l}\text { No income from } \\
\text { this employment }\end{array}$ & $10(3 \%)$ & $145(48 \%)$ & $2(1 \%)$ \\
\hline Less than $£ 5,000$ & $21(7 \%)$ & $74(24 \%)$ & $17(6 \%)$ \\
\hline$£ 5,000-£ 9,999$ & $31(10 \%)$ & $34(11 \%)$ & $19(6 \%)$ \\
\hline$£ 10,000-£ 19,999$ & 77 (25\%) & $22(7 \%)$ & $73(25 \%)$ \\
\hline$£ 20,000-£ 29,999$ & $87(28 \%)$ & $4(2 \%)$ & $89(30 \%)$ \\
\hline$£ 30,000-£ 39,999$ & $53(17 \%)$ & $4(2 \%)$ & $68(23 \%)$ \\
\hline$£ 40,000-£ 49,999$ & $18(6 \%)$ & $2(2 \%)$ & $19(6 \%)$ \\
\hline$£ 50,000+$ & $6(2 \%)$ & $0(0 \%)$ & $11(4 \%)$ \\
\hline
\end{tabular}

Respondents had the greatest WTE employment in the North West and Northern Ireland. Mean music therapy income was lower (under $£ 20,000$ ) in the four following areas (starting with the lowest): Wales, North-East, Central South and Scotland (Figure 7).

$<$ Insert figure 7 here $>$

Employment activities. The majority of respondents' employment activities constituted clinical work. Student placements or supervision were provided by 
132 therapists (27\%), whilst clinical supervision of qualified practitioners was provided by $75(15 \%)$. Around 10\% undertook research and line management. Within self-employment, $6 \%$ were managing another person or team (Table 2).

Table 2. Employment activities.

\begin{tabular}{|l|l|l|l|}
\hline Employment activities & $\begin{array}{l}\text { Employment } \\
\text { Frequency (\%) } \\
\mathbf{( N = 3 0 5 )}\end{array}$ & $\begin{array}{l}\text { Self- } \\
\text { Employment } \\
\text { Frequency } \\
\mathbf{( \% )} \\
\text { (N=186) }\end{array}$ & $\begin{array}{l}\text { All } \\
\text { respondents } \\
\text { Frequency } \\
\mathbf{( \% )} \\
(\mathbf{N = 4 9 1 )}\end{array}$ \\
\hline Clinical work & $263(86 \%)$ & $157(84 \%)$ & $420(86 \%)$ \\
\hline Student placement or supervision & $104(34 \%)$ & $28(15 \%)$ & $132(27 \%)$ \\
\hline Music therapy clinical supervision & $50(16 \%)$ & $25(13 \%)$ & $75(15 \%)$ \\
\hline Research & $42(14 \%)$ & $7(4 \%)$ & $49(10 \%)$ \\
\hline Line management & $44(14 \%)$ & $3(2 \%)$ & $47(10 \%)$ \\
\hline Team management & $36(12 \%)$ & $8(4 \%)$ & $44(9 \%)$ \\
\hline $\begin{array}{l}\text { Higher Education Institution (HEI) } \\
\text { teaching }\end{array}$ & $31(10 \%)$ & $7(4 \%)$ & $38(8 \%)$ \\
\hline $\begin{array}{l}\text { Non-music therapy clinical } \\
\text { supervision }\end{array}$ & $25(8 \%)$ & $13(7 \%)$ & $38(8 \%)$ \\
\hline Other & $26(9 \%)$ & $8(4 \%)$ & $34(7 \%)$ \\
\hline
\end{tabular}

Music therapy capacity and demand.

This section of the survey covered the number of sessions offered per week, duration of therapy and caseload of music therapists. Respondents with employment contracts most frequently offered 4 individual sessions ( $N=26,12 \%)$ 
and 1 group session (N-70,32\%) per week. Self-employed therapists tended to offer 1 individual session $(\mathrm{N}=16,11 \%$ and 1 group session $(\mathrm{N}=33,24 \%)$ per week.

Durations of music therapy were similar for both employed and self-employed music therapists. Respondents most frequently reported durations of 7 months or longer for music therapy with less than $5 \%$ reporting a single session or durations less than 1 month. Employed practitioners saw clients on average for 29.5 sessions (s.d. 22.79) whilst self-employed saw clients on average for 33.4 sessions (s.d. 30.63).

Employed and self-employed music therapists had similar numbers of clients on average on their caseload (employed=16.8, s.d. 13.88; self-employed= 13.9 , s.d.=13.61). Employed music therapists had on average more clients waiting to be seen than self-employed (employed=7.35, s.d. 13.99; self-employed=3.50, s.d. 6.95). Most however, reported none waiting to be seen (employed, $N=39,25 \%$; self-employed therapists $\mathrm{N}=32,28 \%$ ). Waiting times from referral to first contact are shown in Table 3. The majority of therapists stated waiting times were not applicable $(28 \%)$ or were uncertain $(12 \%)$ about the length. Waiting times in 
employed music therapists tended to be longer, with $33 \%$ of clients waiting 3 months or longer, compared to $13 \%$ in self-employment.

Table 3. Waiting time to be seen from referral to first contact.

\begin{tabular}{|l|l|l|l|}
\hline Waiting time & $\begin{array}{l}\text { Self-employed } \\
\text { Frequency (\%) } \\
\text { (N=153) }\end{array}$ & $\begin{array}{l}\text { Employed } \\
\text { Frequency (\%) } \\
\text { (N=235) }\end{array}$ & $\begin{array}{l}\text { All respondents } \\
\text { Frequency (\%) } \\
\text { (N=388) }\end{array}$ \\
\hline 1 day & $5(3 \%)$ & $5(2 \%)$ & $10(3 \%)$ \\
\hline 5 days & $12(8 \%)$ & $13(6 \%)$ & $15(4 \%)$ \\
\hline 2 weeks & $22(14 \%)$ & $28(12 \%)$ & $50(13 \%)$ \\
\hline 1 month & $19(12 \%)$ & $29(12 \%)$ & $48(12 \%)$ \\
\hline 2 months & $10(7 \%)$ & $19(8 \%)$ & $29(8 \%)$ \\
\hline 3 months & $12(8 \%)$ & $27(12 \%)$ & $39(10 \%)$ \\
\hline More than 3 months & $7(5 \%)$ & $25(11 \%)$ & $32(8 \%)$ \\
\hline Unsure/don't know & $19(12 \%)$ & $26(11 \%)$ & $45(12 \%)$ \\
\hline Not applicable & $47(31 \%)$ & $63(27 \%)$ & $110(28 \%)$ \\
\hline
\end{tabular}

Respondents assessed that demand for their services was high with only 4\% reporting fewer referrals than their availability (Table 4). Demand on employed services was slightly higher than self-employed, with $42 \%(N=119)$ of those in 
employment reporting "more referrals than I can see", compared to $34 \%(\mathrm{~N}=53)$ of self-employed.

Table 4. Demand for music therapy

\begin{tabular}{|l|l|l|l|}
\hline Demand for music therapy & $\begin{array}{l}\text { Self- } \\
\text { employed } \\
\text { Frequency } \\
\text { (\%) (N=157) }\end{array}$ & $\begin{array}{l}\text { Employed } \\
\text { Frequency } \\
\mathbf{( \% )} \\
\mathbf{( N = 2 8 2 )}\end{array}$ & $\begin{array}{l}\text { All } \\
\text { respondents } \\
\text { Frequency } \\
\mathbf{( \% )} \\
\mathbf{( N = 4 3 9 )}\end{array}$ \\
\hline $\begin{array}{l}\text { Fewer referrals than available } \\
\text { slots }\end{array}$ & $10(6 \%)$ & $7(3 \%)$ & $17(4 \%)$ \\
\hline Just about right & $56(36 \%)$ & $93(33 \%)$ & $149(34 \%)$ \\
\hline More referrals than I can see & $53(34 \%)$ & $119(42 \%)$ & $172(39 \%)$ \\
\hline Not applicable & $38(24 \%)$ & $63(22 \%)$ & $101(23 \%)$ \\
\hline
\end{tabular}

Work settings, client and age groups.

In total, 920 settings were served by 327 therapists across 491 posts (Figure 8). The most commonly reported settings were special educational needs schools (38\% of all posts $(\mathrm{N}=185)$, served by 160 therapists ( $48 \%$ of all therapists)), mainstream schools $(17 \%$ of all posts $(\mathrm{N}=84)$, served by 78 therapists, $(24 \%$ of all 
therapists)), care homes ( $17 \%$ of posts $(\mathrm{N}=83)$, served by 83 therapists, $(25 \%))$ and private settings ( $15 \%$ of posts ( $N=75)$, served by 73 therapists $(22 \%)$ ).

$$
<\text { Insert figure } 8 \text { here> }
$$

Respondents worked with a wide range of client groups: Learning disabilities, autistic spectrum disorders and emotional and behavioural disorders were the most frequent (Table 5).

Table 5. Number of music therapy posts and music therapists per client group.

\begin{tabular}{|l|l|c|c|}
\hline Client categories & \multicolumn{1}{|c|}{ Client group } & $\begin{array}{c}\text { Number of } \\
\text { posts with } \\
\text { client group } \\
\text { (N=491) }\end{array}$ & $\begin{array}{c}\text { Number of } \\
\text { respondents } \\
\text { (N=327) }\end{array}$ \\
\hline \multirow{2}{*}{$\begin{array}{l}\text { Developmental } \\
\text { and behavioural } \\
\text { disorders }\end{array}$} & Autistic Spectrum disorders & 298 & 231 \\
\cline { 2 - 4 } & Emotional \& behavioural disorders & 262 & 202 \\
\cline { 2 - 4 } $\begin{array}{l}\text { Parents and } \\
\text { families }\end{array}$ & Learning disabilities & 305 & 242 \\
\hline \multirow{4}{*}{ Mental health } & Family work & 93 & 87 \\
\cline { 2 - 4 } & Pastering and adoption & 66 & 60 \\
\cline { 2 - 4 } & Mental health (non-forensic) & 103 & 96 \\
\cline { 2 - 4 } & Mental health (forensic) & 36 & 137 \\
\cline { 2 - 4 } & Drug/alcohol addiction & 34 & 32 \\
\cline { 2 - 4 } & Eating disorders & 50 & 47 \\
\hline
\end{tabular}




\begin{tabular}{|l|l|c|c|}
\hline \multirow{4}{*}{ End of life care } & Bereaved people & 113 & 137 \\
\cline { 2 - 4 } & Palliative care & 65 & 60 \\
\hline \multirow{4}{*}{$\begin{array}{l}\text { Neurological } \\
\text { conditions }\end{array}$} & Brain injury & 116 & 104 \\
\cline { 2 - 4 } & Dementia & 108 & 102 \\
\cline { 2 - 4 } & Epilepsy & 118 & 105 \\
\cline { 2 - 4 } & Motor neurone disease & 21 & 20 \\
\cline { 2 - 4 } & Neurological disorders & 100 & 89 \\
\hline \multirow{4}{*}{$\begin{array}{l}\text { Other medical } \\
\text { conditions }\end{array}$} & Antenatal & 8 & 8 \\
\cline { 2 - 4 } & Cancer & 53 & 49 \\
\cline { 2 - 4 } & Lung diseases & 25 & 24 \\
\cline { 2 - 4 } & Neonatal & 15 & 15 \\
\hline \multirow{5}{*}{$\begin{array}{l}\text { Other client } \\
\text { groups }\end{array}$} & Asylum seekers & 21 & 23 \\
\cline { 2 - 4 } & Criminal offenders & 13 & 13 \\
\cline { 2 - 4 } & Homelessness & 10 & 10 \\
\cline { 2 - 4 } & MT students (personal therapy) & 32 & 31 \\
\cline { 2 - 4 } & Self-referred no diagnosis & 50 & 67 \\
\cline { 2 - 4 } & Stress management & 74 & 23 \\
\cline { 2 - 4 } & Sexual abuse & 19 & 19 \\
\cline { 2 - 4 } & Other & & \\
\cline { 2 - 4 } & Not applicable & 28 & 24 \\
\hline
\end{tabular}

To facilitate interpretation, client groups were grouped into broader categories: 'developmental and behavioural disorders', 'parents and families', 'mental health', 'end of life care', 'neurological conditions', 'other medical conditions' and 'other client groups'. Of these, developmental and behavioural needs, neurological conditions and mental health were the most frequent (Figure 9). 
Respondents reported working across the lifespan. Work with children and adolescents was most common (78\% of all posts). The proportion of music therapists working with older adults was lower in comparison to other age groups; $126(39 \%)$ respondents worked with older adults, in 141 posts (29\% of all posts) compared to around $50 \%$ of music therapists working in all other age categories (Figure 10).

$<$ Insert figure 10 here $>$

Music therapy and supervision fees (self-employment).

This section refers to 'self-employment', 'private practice' or 'freelance' work. Just over half of practitioner members had some self-employed work $(\mathrm{N}=186,57 \%)$. Respondents offered a range of self-employed activities, with many offering more than one type of activity. The most common activities were individual music therapy (44\%) and supervision (41\%), whilst group music therapy was offered by $35 \%$ and community music therapy by $12 \%$. 
Supervision fees ranged from $£ 29-£ 100$ with $£ 40$ being the most common sessional and hourly rate. Most reported that their fee was set following BAMT guidance $(\mathrm{N}=111,63 \%)$ or speaking with other music therapists $(\mathrm{N}=92,53 \%)$. At the time of the survey, no concrete fees were set by BAMT as guidance on their website, although respondents may have corresponded directly with the organisation for advice.

Respondents charged their music therapy fees according to different units (e.g. sessional, hourly) (Table 6). Many noted in open responses that they operated a flexible or sliding scale depending on client group, circumstances and who is paying. Some charged upper rates if being paid by an organisation.

Table 6. Music therapy fees.

\begin{tabular}{|l|l|l|l|l|l|l|}
\hline \multicolumn{2}{|c|}{} & \multicolumn{2}{|l|}{$\begin{array}{l}\text { Individual music } \\
\text { therapy }\end{array}$} & \multicolumn{2}{l|}{ Group music therapy } & \multicolumn{2}{l|}{$\begin{array}{l}\text { Community music } \\
\text { therapy }\end{array}$} \\
\cline { 2 - 7 } & $\begin{array}{l}\text { Range of } \\
\text { fees }\end{array}$ & $\begin{array}{l}\text { Most } \\
\text { common } \\
\text { fee } \\
\text { (mode) }\end{array}$ & $\begin{array}{l}\text { Range of } \\
\text { fees }\end{array}$ & $\begin{array}{l}\text { Most } \\
\text { common } \\
\text { fee } \\
\text { (mode) }\end{array}$ & $\begin{array}{l}\text { Range of } \\
\text { fees }\end{array}$ & $\begin{array}{l}\text { Most } \\
\text { common } \\
\text { fee } \\
\text { (mode) }\end{array}$ \\
\hline $\begin{array}{l}\text { Sessional } \\
\text { rates }\end{array}$ & $£ 17.50-£ 60$ & $\begin{array}{l}£ 40 \\
(\mathrm{~N}=61)\end{array}$ & $£ 30-£ 115$ & $\begin{array}{l}£ 60 \\
(\mathrm{~N}=38)\end{array}$ & $£ 30-£ 90$ & $\begin{array}{l}£ 50 \\
(\mathrm{~N}=23)\end{array}$ \\
\hline $\begin{array}{l}\text { Hourly } \\
\text { rates }\end{array}$ & $£ 21-£ 100$ & $\begin{array}{l}£ 35 \\
(\mathrm{~N}=75)\end{array}$ & $£ 21-£ 120$ & $\begin{array}{l}£ 35 / £ 40 \\
(\mathrm{~N}=55)\end{array}$ & $£ 30-£ 120$ & $\begin{array}{l}£ 50 \\
(\mathrm{~N}=12)\end{array}$ \\
\hline
\end{tabular}




\begin{tabular}{|l|l|l|l|l|l|l|}
\hline $\begin{array}{l}\text { Per half } \\
\text { day }\end{array}$ & $£ 95-£ 110$ & $\begin{array}{l}£ 95 / £ 110 \\
(\mathrm{~N}=2)\end{array}$ & $£ 100-£ 150$ & $\begin{array}{l}-\mathrm{a} \\
(\mathrm{N}=3)\end{array}$ & $£ 85-£ 170$ & $\begin{array}{l}£ 100 \\
(\mathrm{~N}=4)\end{array}$ \\
\hline Per day & $£ 41-£ 250$ & $\begin{array}{l}£ 210 \\
(\mathrm{~N}=12)\end{array}$ & $£ 160-£ 250$ & $\begin{array}{l}£ 220 \\
(\mathrm{~N}=6)\end{array}$ & $£ 160-£ 250$ & $\begin{array}{l}-\mathrm{a} \\
(\mathrm{N}=4)\end{array}$ \\
\hline $\begin{array}{l}\text { Per client } \\
\text { in group }\end{array}$ & $\begin{array}{l}\text { None } \\
\text { reported }\end{array}$ & $\begin{array}{l}\text { None } \\
\text { reported }\end{array}$ & $£ 10-£ 45$ & $\begin{array}{l}£ 35 \\
(\mathrm{~N}=5)\end{array}$ & $\begin{array}{l}\text { None } \\
\text { reported }\end{array}$ & $\begin{array}{l}\text { None } \\
\text { reported }\end{array}$ \\
\hline
\end{tabular}

a Each fee reported by respondents was different, with no most common or frequently occurring fee.

Some expressed their wish for more guidance regarding how to set fees along with a concern regarding instances where services had been offered for free or at a reduced rate. Requests for guidance included: advice when setting up new posts, communicating guidance to trainees and how to set expectations for working arrangements with employers. This included a need for support with cost of living raises or salary scales, payment for time to process and reflect upon therapeutic work (including notes and report writing), continuing professional development and supervision.

Others expressed concern regarding the difficulty of communicating the nature of their self-employed and freelance work within the survey design. Some noted arrangements where whilst working for a large employer, such as a Local Education Authority (LEA), services paid only for 'contact time' with clients, effectively likening the work to self-employment, yet holding a contract with the 
employer. Others held contracts with one employer but had work spread across multiple settings and sites. Some described work that they felt would not conventionally be categorised as 'music therapy' (such as wider music and health initiatives, or managerial and teaching roles) yet brought their music therapy skills into this work.

Music therapy funding and commissioning.

The most common sectors of work were the charitable sector $(\mathrm{N}=138,29 \%)$, followed by private practice $(\mathrm{N}=113,24 \%)$, Local Education Authorities (LEA) $(\mathrm{N}=82,17 \%)$ and the National Health Service (NHS) $(\mathrm{N}=68,14 \%)$ Concurrently, the largest funders of music therapy posts were charities (42\%), followed by LEAs (28\%), the private sector (26\%) and the NHS (18\%).

Just over half (56\%) of music therapy contracts were permanent, whilst there was evidence of honorary $(\mathrm{N}=3)$, zero hours $(\mathrm{N}=3)$ and in 19 cases no contracts in place for the work that was happening. The most common $(\mathrm{N}=110)$ contract duration was 12 months for both employment and self-employment (range 7 days - 36 months). Some noted the variable nature of private practice and fees, and that 
contracts were often negotiated with clients' parents or a client for a fixed number of sessions. Some were dependent on the funding available, so contract status was determined by the level of funds.

Commissioning of new posts and changes to hours worked. Sixty new posts were commissioned in the year preceding the survey, which constitute $21 \%$ of all employed posts reported. A similar picture was seen within self-employed work, with 37 new pieces of work, constituting 23\% of self-employed posts reported.

There was a large variation in respondents' reporting of changes in hours, with $50 \%$ of all posts either increasing or decreasing in the last year. One third of posts $(\mathrm{N}=150)$ increased in hours, whilst $17 \%$ of posts $(\mathrm{N}=77)$ reduced. The number of hours changed was relatively similar with an average change of just over 1 working day (8.83 hours increase vs. 8.58 hours decrease) and mode change of 1 working day. Whilst on average this picture suggests an expansion of music therapy work, it should be noted that for some individuals, hours reduced by up to 32 hours, or 4.5 days. This survey also did not ask specifically if jobs or posts were lost. 
Reasons for the change in hours were provided for 129 reported posts. The most frequent reasons for an increase in hours were an increase in demand for music therapy services, the employer requesting more input and replacing hours left by colleagues either leaving posts or maternity leave. The most frequent reason for reductions in hours was personal choice, either due to return from maternity leave and family commitments, respondents' wish to reduce hours from full-time to part time and reducing to take up new work elsewhere.

\section{Discussion}

The findings provide an overview of music therapists' demographics, training and employment characteristics in the UK. As an initial mapping of the workforce, they offer an insight into areas for potential future action including areas that relate to music therapy practice, training and research. In an attempt to understand the present and re-vision the future, below we provide a situated summary of key findings along with a discussion of this study's strengths, limitations and implications.

Understanding the present: A situated summary of key findings

Most of the survey respondents were female, white and of British nationality. This suggests a limited diversity within the UK workforce and may relate to the 
observed trend for females to work in caring professions (e.g. The King's Fund, no date; Office for National Statistics, 2013) and the general demographic of undergraduates studying in creative arts degrees (Higher Education Statistics Agency, 2016). Given that over half of the respondents had qualified in 2005 or later, the findings seem to be more representative of employment of more recent graduates. The growth in HCPC registered music therapists (423 between 20062016), may account for this larger proportion of more recently qualified member responses. The respondents to Stewart's survey (2000) conducted almost 20 years previously, was also characterised by high numbers of newly qualified practitioners and a similar demographic.

Questions of strategic interest might include how the BAMT membership maps on to population level data for the UK and whether the lower numbers of male and non-white respondents is similar to that of other allied health professions.

Whilst the recent economic climate has raised concerns for music therapy posts, some optimistic messages can be drawn from this survey. Most newly qualified therapists found work within 6 months of qualification; around 60 new posts were set up within the year prior to the survey and changes to hours in posts tended to 
include an increase in hours or reductions by choice. Most respondents had music therapy employment and worked on average for 3 days per week (similar again, to Stewart's (2000) study). It should be noted that this survey did not ask about posts that were lost and it may be that therapists for whom work had been lost did not participate in this survey. We recommend that future studies include questions about posts lost and identify strategies to engage therapists who may, due to professional, financial or personal reasons, not be BAMT members.

The diversity of employment situations and practices may suggest that music therapists adapt their practice to respond to the needs of their work setting or situation. Respondents, for example, reported community-oriented practices, further training and accreditation in associated disciplines, wider team management and supervision of therapists. Some respondents expressed their concern and need for guidance around the language used to communicate the profession of music therapy, particularly for greater clarity of the remit and scope of their work with funders and providers. In contrast to these positive developments, it was clear that for some respondents, finding and keeping work with good standards of employment was an ongoing challenge. This particularly related to negotiation of contracts and payment, uncertainty of funding and in 
some cases, zero hours or no contracts at all. Further work to produce professional guidance on setting up and negotiating employment within different settings may assist practitioners in advocating on these matters. Despite the issues outlined above, only one third of respondents were members of a trade union and the reasons for this would also benefit from further exploration.

Similar to Stewart (2000) and the APMT (2010) survey, the most commonly reported client group and setting remained learning difficulties and education. This survey, however, identified a larger number of music therapists working with adolescents and older adults, as well as with people with dementia and neurological conditions. This growth may have been influenced by increased initiatives to improve care for these client groups and wider music therapy research to evidence this (e.g. Derrington, 2012; Hung Hsu et al., 2015; Magee et al., 2016). The largest funder of music therapy was the charitable sector. In contrast, the number of respondents employed by the NHS was relatively small, despite this being the largest single employer of music therapists in the country.

Whilst the employment situation of respondents portrayed a generally positive image, the survey findings suggest wider issues regarding capacity and demand. 
UK coverage of respondents amounted to less than 20 therapists per area outside of the South of England, and only 38 therapists for the whole of Scotland. The majority of respondents were London-based and accounted for $25 \%$ of the sample whilst only $18 \%$ were in full-time employment. Whilst Stewart's survey (2000) was conducted in part, due to observations of geographical isolation at the time, data on the spread of music therapists across the UK were not presented. He notes however, the 'portfolio' nature of respondents' work at the time alongside observations from within the APMT at the time of a lack of full-time work opportunities. Possible factors may include employers commissioning less than full-time posts, difficulty in creating posts outside of urban areas (particularly London), the intensity of therapeutic work, a wish to balance work with other roles outside of the profession and family or caring commitments. As Stewart (2000) notes, the opportunity to build a flexible portfolio of work in balance with other commitments may actually support music therapists in their role and appears to remain a relevant concern.

Few respondents provided clinical supervision to other music therapists. This may limit both provision of training placements and access by current music therapists. Stewart (2000) identified a correlation between level of support and job 
satisfaction, of which individual supervision was ranked as most important. Strategies to ensure future capacity, given the growth in registered music therapists may also need consideration.

Respondents worked with an average of 16 clients per week, with a further 3-8 clients waiting to be seen. With waiting times of 2 weeks to one month, around half of therapists reported they had more referrals than they could see. Jointly, the findings raise a number of questions for the profession and its stakeholders, highlighting areas for further exploration. For example, as the workforce and increases, how might we position ourselves strategically to best meet demand and client needs across the UK? Such questions require consideration and debate both locally and nationally, as well as with the BAMT and wider charitable and statutory service providers and funders.

\section{Strengths and limitations of the study}

This is the most comprehensive survey to have been conducted of the music therapy workforce since Stewart's (2000) survey, 16 years ago. Despite the scale of data collected, the survey serves only as an initial mapping of the music therapy workforce. As such, it does not provide any information regarding relationships 
between characteristics or trends across time. The survey targeted BAMT members since these represent the majority of practising music therapists in the UK. ${ }^{9}$ Whilst the response rate (44\%) was generally good for a survey of this kind, $49 \%$ of BAMT practitioners did not respond. When comparing the 327 practitioner survey responses to the 873 music therapists registered with the HCPC at that time, the survey may have missed up to $63 \%$ of music therapists. The survey provides therefore only a limited picture and may have missed music therapists who had recently lost or changed employment as well as non-BAMT members. Including these music therapists is therefore important for future research initiatives. Future studies may benefit from collaboration with both BAMT and the HCPC to widen their reach of potential participants.

As noted above, due to the nature of the survey, there were limits in fully capturing the diversity and complexity of respondents' working situations. This was particularly relevant in cases of freelance and short-term work. In designing similar surveys in the future, consultation with freelance practitioners would help to identify how best to record these scenarios and should ask explicitly regarding

\footnotetext{
${ }^{9}$ at the time of the survey, BAMT had a total of 1006 members and 669 of these were practising as music therapists representing $77 \%$ of the 873 HCPC registered music therapists in the UK. According to Sandford (2016), there were 951 HCPC registered music therapists in 2016.
} 
zero hours or absence of contracts. Also, given the diversity of client needs, future surveys may benefit from asking specifically regarding the primary and secondary conditions of clients.

In our attempt to record as fully as possible employment trends, the survey questionnaire became lengthy and somewhat complex. Whilst we made use of advanced electronic survey design, such as skip logic, the process of completion was time consuming and, for some respondents, a complex task. We wish to acknowledge and thank respondents for their commitment, participation and detailed feedback. In addition, whilst the survey was piloted on a small scale, future studies may wish to consider wider piloting, ways to simplify and shorten response options and the frequency at which such surveys are put to the profession.

Finally, respondents indicated a greater diversity of practice than this survey was designed to capture. Some indicated that they had roles outside of formally designated music therapy posts and would use their music therapy skills to respond to their context even if that meant adapting their work. This diversification and reasons for this warrant further investigation, particularly to 
understand if this is in response to a lack of formal music therapy posts, a greater availability of wider music and health or community music roles, or a wish to develop and innovate music therapy skills within specific contexts.

Re-visioning the future?

This survey complements existing research and literature, including case studies which explore the development of music therapy services within the NHS (e.g. Wood, Sandford \& Bailey, 2016) and other contexts (e.g. Cartwright, 2015), as well as studies which look for trends in the field over longer periods of time (e.g. Tsiris, Spiro \& Pavlicevic, 2014).

The survey results may inform wider strategic considerations of BAMT and other stakeholders regarding professional development. To some extent, music therapy in the UK seems to face similar challenges and opportunities to those that other arts therapies face (Burns, 2012). As Maclean and Pestell highlight, the relatively recent integration of health and social care is creating "unfamiliar infrastructures and different routes for commissioning at local levels" (2016, p.30). Funding changes set certain restrictions and altered lengths of commitment, while different 
health and cultural needs seem to emerge in relation to changing demographics (e.g. ageing population and health inequalities).

As highlighted at the Scottish AHP Parliamentary debate (Scottish Parliament, 2015), the arts therapies need to consider how they continue to meet contemporary needs and ensure the optimal growth of the profession. An "improvisatory attitude" (Maclean \& Pestell, 2016) may well be needed in the wearing of our different 'hats' - as allied health professionals, psychological treatment professionals or arts in health practitioners - to identify, interpret and influence political and strategic drivers. Studies that also explore the fit between music therapy and national policies (e.g. Spiro, Farrant \& Pavlicevic, 2017) can help towards this direction. Considering the range of different working environments, there are indicators of the potential to develop our roles beyond direct music therapy services to include partnerships and consultancy by advising, resourcing and training others.

Whilst there may be limited scope in comparing the survey findings with those from similar studies in other countries (given their varied contexts and priorities), some overall composite international findings might be useful. To facilitate such 
composite representation, future studies may need to align their questions and methods to some extent. The recent WFMT survey is one example where future alignment of research questions may help comparability, whilst allowing space for each unique context. In this spirit, we have made the questionnaire used in this study freely available online (Carr, Tsiris \& Swijghuisen Reigersberg, 2017 ). We suggest that professional bodies of individual countries and international bodies, explore these possibilities to facilitate comparison across countries, music therapy contexts and practices. We do not propose uniformity but an agreement on main areas of focus leading potentially to overviews that could contribute to policymaking and professionalisation of music therapy locally and globally (Ridder \& Tsiris, 2015a). Such survey design considerations may also be of interest to other arts therapies and allied health professions.

As signalled in the theme of the 2016 BAMT conference, "Re-Visioning our Voice: Resourcing Music Therapy for Contemporary Needs", there is an urge to look forward and re-imagine our voice. Such re-imagining needs to consider wider socio-political and financial implications. Any kind of re-visioning for the future, however, requires an understanding of the present, and this is where the scope of this study lies. By providing a current picture of the BAMT membership, we hope 
to provide a pragmatic platform upon which questions regarding the development of the profession and its strategic priorities emerge. Such questions can help UK music therapists re-vision their professional voice and to play an active role in shaping the future of music therapy in the UK. 


\section{References}

Aigen, K. (2014). The Study of Music Therapy: Current Issues and Concepts. New York: Routledge.

American Music Therapy Association (AMTA) (2014). A descriptive statistical profile of the 2014 AMTA membership.

Ansdell, G., Bunt, L., \& Hartley, N. (2002). Music therapy in the United Kingdom. $\begin{array}{lll}\text { Voices } & \text { Resources. } & \text { Retrieved }\end{array}$ https://voices.no/community/?q=country-of-the-month/2002-musictherapy-united-kingdom (accessed 11 April 2017).

Ansdell, G., \& Pavlicevic, M. (2008). Responding to the challenge: Between boundaries and borders: A Response to Alison Barrington's article 'Challenging the Profession'. British Journal of Music Therapy, 22(2), 73-76.

Association of Professional Music Therapists (APMT) (2010). APMT Member Statistics 2009-2010. London: APMT.

Barrington, A. (2005). Music therapy: A study in professionalisation. PhD Thesis, Durham University. Retrieved from: http://etheses.dur.ac.uk/2791/ (accessed 11 April 2017).

Barrington, A. (2015). Perspectives on the development of the music therapy profession in the UK. Approaches: Music Therapy \& Special Music Education, Special Issue 7(1), 118-122. $\quad$ Retrieved from 
http://approaches.gr/perspectives-on-the-development-of-the-musictherapy-profession-in-the-uk-alison-barrington/ (accessed 11 April 2017).

Bonde, L. O. (2011). Health musicing - Music therapy or music and health? A model, empirical examples and personal reflections. Music and Arts in Action, 3(2), 120-140. Retrieved from http://musicandartsinaction.net/index.php/maia/article/view/healthmusi cingmodel (accessed 11 April 2017).

Bristol Online Surveys (2015). Bristol Online Surveys Tool. Retrieved from https://www.onlinesurveys.ac.uk/about/ (accessed 15 Nov 2016).

Bristol Online Surveys (2017). Introduction to Routing. Retrieved from https://www.onlinesurveys.ac.uk/help-support/introduction-to-routing-

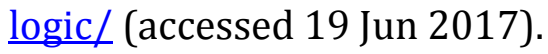

British Association of Music Therapy (BAMT) (2015). 2015 General Assembly, $3^{\text {rd }}$ October 2015, London, UK.

British Association of Music Therapy (BAMT) (2015b). Retrieved from https://www.bamt.org/about-british-association-for-music-therapy/joinus.html (accessed 11 April 2017).

Bruscia, K. (1987). Improvisational Models of Music Therapy. Springfield, IL: Charles C Thomas. 
Bunt, L., \& Stige, B. (2014). Music Therapy: An Art Beyond Words (2nd Edition). New York: Routledge.

Burns, J. (2009). An Interpretive description of the patterns of practice of arts therapists working with clients with dementia. PhD thesis, Queen Margaret $\begin{array}{lll}\text { University, } & \text { Edinburgh. } & \text { Retrieved }\end{array}$ http://etheses.qmu.ac.uk/117/1/117.pdf (accessed 11 April 2017).

Carr, C., Odell-Miller, H., \& Priebe, S. (2013). A systematic review of music therapy practice and outcomes with acute adult psychiatric in-patients. PloS one, 8(8), $\quad$ Retrieved from http://journals.plos.org/plosone/article?id=10.1371/journal.pone.007025 $\underline{2}$ (accessed 11 April 2017).

Carr, C., O’Kelly, J., Sandford, S. \& Priebe, S. (2017). Feasibility and acceptability of group music therapy vs wait-list control for treatment of patients with longterm depression (the SYNCHRONY trial): study protocol for a randomised controlled trial. Trials, 18:149. doi:10.1186/s13063-017-1893-8.

Carr, C., Tsiris, G., \& Swijghuisen Reigersberg, M. (2017). The 2015 BAMT workforce survey questionnaire. Retrieved from www.bamt.org

Cartwright, C. (2015). A voyage of discovery: From fulfilling funding criteria to revealing a clearer vision for music therapy in a special needs school. Approaches: An Interdisciplinary Journal of Music Therapy, First View 
(Advance online publication). Retrieved from http://approaches.gr/avoyage-of-discovery-from-fulfilling-funding-criteria-to-revealing-a-clearervision-for-music-therapy-in-a-special-needs-school-by-claire-cartwright/ (accessed 11 April 2017).

Centre for Workforce Intelligence (CfWI) (2013). Improving workforce planning for the psychological therapies workforce. London: CfWI. Retrieved from: https://www.gov.uk/government/uploads/system/uploads/attachment d ata/file/507554/CfWI Physcological Therapies Workforce indepth review.pdf (accessed 11 April 2017).

Curtis, S. (2015). Profile of community music therapists in North America: A survey. Voices: A World Forum for Music Therapy, 15(1). Retrieved from https://voices.no/index.php/voices/article/view/811/679 (accessed 11 April 2017).

Decuir, A.A., \& Vega, V.P. (2010). Career longevity: A survey of experienced professional music therapists. Arts in Psychotherapy, 43, 174-197.

Dileo-Maranto, C. D. (Ed.). (1993). Music Therapy: International Perspectives. Pipersville, PA: Jeffrey Books.

Department for Education (2016). Financial sustainability of schools. London: National Audit Office. Retrieved from https://www.nao.org.uk/wp- 


\section{content/uploads/2016/12/Financial-sustainability-of-schools.pdf}

(accessed 11 April 2017).

Derrington, P. (2012). An investigation into the effectiveness and value of music therapy with young people, aged 11-14 years, at risk of under-achieving or exclusion. PhD thesis. Cambridge: Anglia Ruskin University.

Field, A. (2009). Discovering statistics using SPSS. Third Edition. London: Sage Publications.

Geretsegger, M., Holck, U., \& Gold, C. (2012). Randomised controlled trial of improvisational music therapy's effectiveness for children with autism spectrum disorders (TIME-A): study protocol. BMC Pediatrics, 12(2). $\begin{array}{lll}\text { Retrieved } & \text { from }\end{array}$ http://bmcpediatr.biomedcentral.com/articles/10.1186/1471-2431-12-2 (accessed 11 April 2017).

Groene, R. (2003). Wanted: Music therapists: A study of the need for music therapists in the coming decade. Music Therapy Perspectives, 21, 4-14.

Higher Education Statistics Agency (2016). Free online statistics- students and qualifiers. Retrieved from https://www.hesa.ac.uk/data-and-analysis/students (accessed 11 April 2017).

Hsiao, F. (2014). Gatekeeping practices of music therapy academic programs and internships: A national survey. Journal of Music Therapy, 51(2), 186-206. 
Hung Hsu, M., Flowerdew, R., Parker, M. Fachner, J., \& Odell-Miller, H. (2015). Individual music therapy for managing neuropsychiatric symptoms for people with dementia and their carers: A cluster randomised controlled feasibility study. BMC Geriatrics, 15(84),

The King's Fund (no date). Overview of the health and social care workforce. Retrieved from $\quad \underline{\text { http://www.kingsfund.org.uk/time-to-think- }}$ differently/trends/professional-attitudes-and-workforce/overview-healthand-social-care-workforce (accessed 11 April 2017).

MacDonald, R., Kreutz, G., \& Mitchell, L. (Eds.). (2012). Music, Health and Wellbeing. Oxford: Oxford University Press.

Maclean, E., \& Pestell, K. (2016). Music therapy in a changing landscape. In U. Aravinth, M. Pavlicevic \& G. Watts (Eds.), Re-visioning our voice: Resourcing music therapy for contemporary needs (Second BAMT Conference, 8-10 April 2016, University of Strathclyde, Glasgow) (pp. 30-31). London: British Association for Music Therapy.

Magee, W. L., Siegert, R. J., Daveson, B. A., Lenton-Smith, G., \& Taylor, S. M. (2014). Music Therapy Assessment Tool for Awareness in Disorders of Consciousness (MATADOC): Standardisation of the principal subscale to assess awareness in patients with disorders of consciousness. Neuropsychological Rehabilitation, 24(1), 101-124. 
Maratos, A. (2014). MTUK: Collaboration for the future. Keynote speech, BAMT conference. British Journal of Music Therapy, 28(2), 6-15.

McKenna, H. (2016). Five big issues for health and social care after the Brexit vote. Retrieved from https://www.kingsfund.org.uk/publications/articles/brexit-and-nhs (accessed 11 April 2017).

Nuffield Trust, The Health Foundation \& The King's Fund (2016). The Autumn Statement: Joint statement on health and social care. Retrieved from https://www.nuffieldtrust.org.uk/files/2017-01/autumn-statement-2016web-final.pdf (accessed 11 April 2017).

Odell-Miller, H. (2016). The role, function and identity of music therapists in the $21^{\text {st }}$ century, including new research and thinking from a UK perspective. British Journal of Music Therapy, 30(1), 5-12.

Odell-Miller, H., \& Sandford, S. (2009). Update on music therapy in the United $\begin{array}{llll}\text { Kingdom. } & \text { Voices } & \text { Resources. } & \text { Retrieved }\end{array}$ https://voices.no/community/?q=country/monthuk march2009 (accessed 11 April 2017).

Office for National Statistics (2013). Women in the labour market: 2013. Retrieved from http://www.ons.gov.uk/employmentandlabourmarket/peopleinwork/emp 
loymentandemployeetypes/articles/womeninthelabourmarket/2013-09$\underline{25}$ (accessed 11 April 2017).

Ridder, H. M., \& Tsiris, G. (2015a). 'Thinking globally, acting locally': Music therapy in Europe. Approaches: Music Therapy \& Special Music Education, Special Issue 7(1), 3-9. Retrieved from http://approaches.gr/special-issue-7-12015/ (accessed 11 April 2017).

Ridder, H. M., \& Tsiris, G. (Eds.). (2015b). Special issue: "Music therapy in Europe: Paths of professional development". Approaches: Music Therapy \& Special Music Education, Special Issue 7(1), Retrieved from http://approaches.gr/special-issue-7-1-2015/ (accessed 11 April 2017).

Sandford, S. (2016). Music therapists marching, running and playing with the beat: BAMT Conference plenary session- April 2016. British Journal of Music Therapy, 30(2), 57-64.

Scottish Parliament (2015). Meeting of the parliament 19 $9^{\text {th }}$ May 2015. Official report. Retrieved from:

http://www.scottish.parliament.uk/parliamentarybusiness/report.aspx?r= 9955\&i=91428 (accessed 11 April 2017).

Silverman, M. J., Furman, A. G., Schwartzberg, E. T., Leonard, J., Stephanz, E., \& McKee, R. (2013). Music therapy salaries from 1998-2012: A comparative and descriptive study. Music Therapy Perspectives, 31(2), 181-188. 
Silverman, M. J., \& Furman, A. G. (2014). Employment and membership trends in the American Music Therapy Association, 1998-2009. Music Therapy Perspectives, 32(1), 99-108.

Spiro, N., Farrant, C., \& Pavlicevic, M. (2017). Between practice, policy and politics: Music therapy and the Dementia Strategy, 2009. Dementia, 16(3), 259281.Spiro, N., Tsiris, G., \& Pavlicevic, M. (2014). Music Therapy Models. In B. Thompson, \& G. Golson (Eds.), Music in the Social and Behavioural Sciences: An Encyclopaedia (pp. 771-773). Thousand Oaks, CA: Sage.

StataCorp (2015). Stata Statistical Software: Release 14. College Station, TX: StataCorp LP.

Stegemann, T., Schmidt, H. U., Fitzthum, E., \& Timmermann, T. (Eds.). (2016). Music Therapy Training Programmes in Europe: Theme and Variations. Wiesbaden: Reichert Verlag.

Stige, B., \& Aarø, L. E. (2011). Invitation to Community Music Therapy. New York: Routledge.

Stige, B., Ansdell, G., Elefant, C., \& Pavlicevic, M. (2010). Where Music Helps: Community Music Therapy in Action and Reflection. Aldershot: Ashgate.

Teddlie, C., \& Tashakkori, A. (2009). Foundations of Mixed Methods Research. London: Sage Publications. 
Trondalen, G., \& Bonde, L. O. (2012). Music Therapy: Models and Interventions. In R. MacDonald, G. Kreutz \& L. Mitchell (Eds.), Music, Health and Wellbeing (pp. 40-62). Oxford: Oxford University Press.

Tsiris, G. (Ed.). (2014). Special issue: “Community music therapy”. International Journal of Community Music, 7(1).

Tsiris, G., Spiro, N., \& Pavlicevic, M. (2014). What does the past tell us? A content analysis of the first quarter-century of the British Journal of Music Therapy. British Journal of Music Therapy, 28(1), 4-24.

Tyler, H. (2000).The Music Therapy Profession in Modern Britain. In P. Horden (Ed.), Music as Medicine: The History of Music Therapy since Antiquity (pp. 375-393). Aldershot: Ashgate.

Watson, T. (2015). United Kingdom: Country report on professional recognition of music therapy. Approaches: Music Therapy \& Special Music Education, Special Issue 7(1), 187-188. Retrieved from http://approaches.gr/specialissue-7-1-2015/ (accessed 11 April 2017).

World Federation for Music Therapy (WFMT) (2016). International Survey Study: WFMT \& Music Therapy Consulting Collaboration. Retrieved from http://www.wfmt.info/2016/04/04/international-survey-study-wfmtmusic-therapy-consulting-collaboration/

Wood, J., Sandford, S., \& Bailey, E. (2016). 'The whole is greater'. Developing music 
therapy services in the National Health Service: A case study revisited.

British Journal of Music Therapy, 30(1), 36-46. 